\title{
Sepětí teorie a praxe \\ $v$ systému práce $s$ absolventy \\ na katedře marxisticko-leninské sociologie \\ filozofické fakulty \\ Univerzity Karlovy v Praze
}

Princip sepětí teorie a praxe je ideovým a metodologickým základem výstavby oboru marxisticko-leninské sociologie (dále ML). Specificky se promítá do činnosti všech tř́i kateder (katedra ML sociologie na filozofických fakultách v Praze, Brně a Bratislavě), které zabezpečují výchovu sociologů v ČSSR podle jednotného učebního programu. Tento učební program je cyklicky posuzován a konfrontován $s$ potřebami praxe. Jednou $\mathrm{z}$ forem ověrování tohoto programu je právě systém práce s absolventy.

I když trend práce $s$ absolventy je na většině vysokoškolských oborů trendem inovačním, rozvíjí se systematická práce $s$ absolventy na katedře ML sociologie FF UK v Praze již tradičně. Postupně jsme na katedře vyvinuli relativnè samostatný systém práce s absolventy, který je však prostřednictvím svých činností integrován do celkové výchovně vzdělávací a vědeckovýzkumné práce katedry. Systém práce $s$ absolventy zahrnuje tři základní směry činnosti a jím odpovídající funkce. J de o funkci kvalifikační, vědeckovýzkumnou a komunikativně informační.

Objektem působení systému práce s absolventy jsou absolventi oboru, v současné době absolventi osmnácti absolventských ročníků, tj. školního roku 1966/67-1983/84, což reprezentuje 670 absolventů, včetně 43 cizinců (stav k 1. 1. 1984). Dále popisované funkce a činnosti systému práce $\mathrm{s}$ absolventy nejsou však výhradně vztaženy $\mathrm{k}$ absolventům všech osmnácti absolventských ročníků; některé uvažuji se sedmnácti absolventskými ročníky, tj. školního roku 1966/67-1982/83, což reprezentuje 638 absolventů včetně 42 cizinců. Rozsah absolventského souboru je závislý na čase realizace jednotlivých činností.

Pruní funkce je kvalifikační, zaměřená na prohlubování a zvyšování kvalifikace absolventů prostřednictvím státních rigorózních zkoušek a studia vědecké aspirantury. Od zavedení nového vysokoškolského zákona v r. 1980 státní rigorózní zkoušky představují nejf rekventovanější formu prohlubování a zvyšování kvalifikace. Ve sledovaném období, to je ve školních letech $1980 / 81-$ ZS $1984 / 85$, bylo zařazeno k rigoróznímu řízení celkem 90 uchazečů, přičemž 73 získalo akademický titul PhDr., 14 nevyhovělo a 3 se nedostavili ke zkoušce. V prvním školním roce platnosti nového vysokoškolského zákona, tj. ve školním roce 1980 / /81 byli zařazeni 3 uchazeči, kteří také získali titul PhDr. Ve druhém školním roce bylo zařazeno 16 uchazečů, všichni rovněž získali titul PhDr. Ve třetím školním roce bylo zařazeno k rigoróznímu řízení 30 uchazečů, kteří dosáhli následujících výsledků: 21 vyhovělo, 6 nevyhovělo a 3 se nedostavili ke zkoušce. Ve čtvrtém školním roce bylo zařazeno 31 uchazečů, kteří dosáhli těchto výsledků: 23 vyhovělo a 8 nevyhovělo. V zimním semestru šk. r. 1984/85 bylo zařazeno 10 uchazečů a všichni získali tit ul PhDr. K tomu nutno dodat, že ze 73 absolventů, kteří získali za uvedené období 
akademický titul PhDr., je 71 absolventů oboru ML sociologie na FF UK v Praze a 2 absolventi příbuzných oborů. 71 absolventů s titulem PhDr. představuje $11 \% \mathrm{z}$ cekového počtu 670 absolventů oboru ML sociologie na FF UK v Praze. Počet absolventů s titulem PhDr., kteři vystudovali obor ML sociologie na FF UK v Praze, je ovšem vyšší, činí odhadem $20 \%$ (zahrnuje také absolventy, kteří získali tento titul na jiných filozofických fakultách nebo před platností nového vysokoškolského zákona apod.)

Katedra ML sociologie je $\mathrm{v}$ současné době školícím pracovištěm 24 aspirantů (stav k 1. 10. 1984), kteří studují v různých formách aspirantury (jeden aspirant školícího pracoviště, 7 aspirantů v samostatné vědecké přípravě, 15 externích aspirantů, 1 aspirant $v$ externí účelové aspirantuře). Ze čtyřiadvaceti aspirantů je třináct absolventů oboru $(54 \%)$ a jedenáct absolventů jiných oborů ( $46 \%$ ). V oboru ML sociologie pracuje na FF UK samostatná komise pro obhajoby kandidátských prací. Před touto komisí obhájilo již osm aspirantů svou kandidátskou disertaci. $Z$ tohoto počtu je sedm absolventů našeho oboru (včetně 1 cizince) a $z$ těchto 7 aspirantů jsou tři aspiranti zároveň učiteli katedry (stav k 5. 6. 1984). I když vědecká aspirantura představuje v práci katedry rozsáhlou činnost (srovnej počet čtyřiadvaceti aspirantů s počtem dvaatřiceti studentů denního studia a počtem 19 studentů dálkového studia!), touto formou si zvyšovala nebo zvyšuje kvalifikaci jen nepatrná část absolventů oboru, přibližně $3 \%$ absolventů. Pochopitelně úplný počet všech aspirantů a kandidátů věd a jejich podíl na celkovém počtu absolventů je vyšší, činí cca $5 \%$ (a to jde o absolventy, kteři studují nebo dokončili aspiranturu na jiných školících pracovišsích).

Vzhledem $\mathrm{k}$ tomu se stává naléhavou potřebou zavést mezistupeň mezi masovějším zvyšováním kvalifikace pomocí státních rigorózních zkoušek (týká se ási $12 \%$, resp. $20 \%$ absolventů) a výběrovým aspirantským studiem ( $3 \%$, resp. $5 \%$ ). Tímto mezistupněm by mělo být postgraduální studium, určené absolventům oboru, a to bud' inovačního nebo specializační- ho typu. $\mathrm{K}$ tomu však katedra potřebuje získat odpovídající materiální a kádrové předpoklady.

Druhou funkcí je vědeckovýzkumná funkce, která je uskutečňována $\mathbf{v}$ podobě „Srovnávacího výzkumu absolventů oboru marxisticko-leninské sociologie, oboru výchova a vzdělávání dospělých FFUK v Praze a oboru výchova a vzdělávání dospělých FF UPJS v Prešově“" (dále jen SVA). Celý průběh tohoto výzkumu zahrnuje období od listopadu 1982 do konce roku 1985. V roce 1984 probíhá etapa terénního šetření a současně jsou zahajovány přípravné práce pro zpracování dat ve Výpočetním středisku Vふ\$E v Praze.

Rešitelský tým SVA tvoři tři učitelé a jeden aspirant katedry ML sociologie FF UK, dva učitelé participujícího prešovského oboru a jeden pracovník výpočetního střediska.

Cílem SVA je zjistit zpětnou vazbu výchovně vzdělávacího působení příslušných oborů, diagnostikovat problematiku společenského uplatnění absolventů $v$ praxi. Bezprostředně je výzkum zaměřen na tyto tematické okruhy: a) sféry společenského uplatnění absolventů $v$ praxi,

b) socioprofesní mobilitu absolventů,

c) úroveň vysokoškolské přípravy absolventů pro výkon profese $\mathrm{v}$ oboru,

d) vzdělávací potřeby absolventů (realizované i potenciální).

Vzhledem $k$ tomu, že jde o srovnávací výzkum, je hlavním metodologickým principem srovnávací metoda. Tato metoda je především uplatněna na ose interoborové komparace, tj. ve srovnání oboru ML sociologie a oboru VVD (výchova a vzdělávání dospělých). Cástečně též budeme srovnávat meziuniverzitně, tj. obor ML sociologie a obor $V V \Gamma$, pěstované na UK s oborem VVD, pěstovanymm na UPJS.

SVA použivá tyto výzkumné techniky: anketu, doprovázenou evidenčním listem absolventa (jako společný materiál), a individuální polostandardizovaný rozhovor.

Objektem výzkumu jsou absolventi od prvního absolventského ročníku do absolventského ročníku školního roku 1982/83. V případě oboru ML sociologie základní soubor tvoří 596 absolventů (bez cizinců), u oboru VVD FF 
UK tvoří základní soubor 373 absolventi. Vzhledem ke specifickým funkcím výzkumů absolventů (jakou jsou výchovně vzdělávací a komunikativně informační funkce), vychází SVA z koncepce kvazi vyčerpávajícího šetření. $\mathrm{V}$ důsledku toho jsme při výběru vzorku ankety (s evidenčním listem) vycházeli $\mathrm{z}$ tohoto předpokladu. Materiály ankety a evidenčního listu jsme tudíz postupně zasílali všem dostupným absolventům. Tím jsme získali výběrové soubory; výběrový soubor oboru ML sociologie činí zhruba 496 absolventů a pražského oboru VVD 333 absolventů.

Vzorek respondentů pro individuální polostandardizovaný rozhovor byl získán „samovýběrem", tj. rozhovor je veden s těmi respondenty, kteří o rozhovor projevili zájem. Rozhovory vedou nejen členové řešitelského týmu, ale také tazatelé $\mathrm{z}$ r̆ad absolventů. Absolventi tedy vystupují nejen $v$ roli respondentů, ale někteři současně i v roli tazatelů. Tazatelé byli vybíráni nejen $s$ ohledem na zastoupení jednotlivých absolventských ročníků, geografických oblastí a institucí, kde absolventi působí, ale také $\mathrm{s}$ ohledem na etické předpoklady $\mathrm{k}$ výzkumné práci. Cílem použití absolventů v roli- tazatelů byly nejen racionalizační důvody, ale i rozvíjení kontaktů a spolupráce $s$ absolventy.

Sběr dat prostřednictvím ankety a evidenčního listu probíhal od dubna do listopadu 1984 a sběr dat prostřednictvím individuálního polostandardizovaného rozhovoru probíhá od záři do prosince 1984. Návratnost ankety (s evidenčními listy) je u absolventů oboru ML sociologie cca $50 \%$, pražského oboru VVD cca $60 \%$ a prešovského oboru VVD je podobná zkoumaným pražským oborům. Návratnost rozhovorů zatím nemohla být spočítána, poněvadž rozhovory nebyly dosud ukončeny.

Praktickým vyústěním SVA bude optimalizace učebních plánů, zpřesnění profilu absolventa, formulace společenské potřeby absolventů i konstituování adekvátních forem dalšího vzdělávání absolventů. Uživateli výstupů a výsledků SVA budou kromě př́íslušných kateder a fakult, oborové rady i mimofakultní orgány, především MŠ, ČR, MŠ SSR a FMPSV.

Třetí funkcí je funkce komunikativně infor- mační, která se projevuje $\mathrm{v}$ různých formách předávání a výměny informací mezi katedrou a absolventy. Dlouhodobě byla na katedře rozvíjena spontánní a neorganizovaná komunikace $s$ absolventy. Tyto neformální kontảkty přispěly $\mathrm{k}$ navázání spolupráce $\mathrm{s}$ institucemi $\mathrm{v}$ oboru, a to jak v oblasti výzkumné, tak pedagogické práce. Souběžně byla také rozvíjena organizovaná komunikace $s$ absolventy ve formě pravidelných schůzek se skupinou absolventů určitého absolventského ročníku. $\mathrm{Na}$ těchto schůzkách byly předávány informace o současné situaci na katedře, o učebním plánu, o vědeckovýzkumné práci, o možnostech rigorózního řizení, studia vědecké aspirantuty apod.

V posledním období byla organizovaná komunikace institucionalizována $\mathrm{v}$ souvislosti se vznikem Rady absolventů, která byla založena při katedře ML sociologie FF UK v květnu 1983. Rada absolventů spadá pod pravomoc katedry a je katedrou řízena na základě statutu. Posláním Rady je rozvíjet a organizovat spolupráci mezi katedrou a absolventy, prohloubit jejich pracovní kontakty a vzájemnou informovanost o odborné činnosti. Toto poslání je realizováno dvěma základními úkoly. Prvním úkolem je organizační příprava pravidelných setkání katedry ML sociologie s absolventy. Druhým úkolem je víceméně periodické vydávání bulletinu „Informace pro absolventy oboru ML sociologie".

Cílem setkáni katedry s absolventy je výměna informací mezi oběma stranami a kodifikace konkrétních forem spolupráce. Katedra ML sociologie plánuje setkání ve dvouletých intervalech; první setkání se konalo v roce 1983, druhé proběhne v roce 1985.

Pruní setkání kateơry ML sociologie s absolventy se konalo 28. ř́ijna 1983 ve velkém sále Svazu českých novinářů v Praze. Připravila je Rada absolventů společně $s$ některými učiteli katedry. Zúčastnilo se 160 absolventů ze sedmnácti absolventských ročníků, členové katedry a hosté. $\mathrm{Z}$ host ů nutno jmenovat tyto osobnosti: nestor české sociologie prof. dr. Karel Galla, DrSc., pracovnice OV KSČ Prahy 1 s. dr. Stanislava Kašparová, CSc., zástupce ministerstva školství doc. dr. Ladislav M. Sobotka, CSc., 
spolupracovník katedry prof. dr. Rudolf Franěk, CSc., vedoucí výzkumného oddělení Čs. rozhlasu dr. Jaroslav Košt'ál, CSc., a doc. dr. Marie Dohalská, CSc., z FF UK. V sále, v němž se.konalo setkání, byla instalována výstavka publikací učitelů i absolventů.

Ústředním tématem prvního setkání byl „Vztah sociologické teorie a praxe $\mathrm{v}$ diskusi učitelů a absolventů katedry". Hlavní referát přednesl vedouci katedry prof. dr. Antonín Vaněk, DrSc. Hovořil o činnosti a úkolech katedry i oboru ML sociologie. Další př́íspěvky přednesl předseda Rady absolventů a další představitelé Rady; učitelé katedry i hosté. V diskusi vystoupili absolventi oboru a spolupracovníci srovnávacího výzkumu. Přijaté závěry konkretizovaly spolupráci katedry s absolventy i činnost Rady absolventů.

První setkání bylo důkladnĕ hodnoceno vedením katedry i Radou absolventů a bylo konstatováno, že vytčené cíle byly splněny. Absolventi hodnotili pruní setkání prostřednictvím ankety, která byla rozeslána jako součást 2. čísla bulletinu „Informace pro absolventy oboru ML sociologie". Referáty o prvním setkání byly uveřejněny ve druhém čísle Sociologického časopisu a v druhém čísle bulletinu pro absolventy.

Při přípravě druhého setkání budeme vycházet nejen $\mathrm{z}$ vlastních zkušeností a námětů $\mathrm{z}$ ankety, ale také $\mathrm{z}$ cenných zkušeností prešovské katedry vysokoškolské pedagogiky, výchovy a vzdělání dospělých. Tato katedra uskutečnila se svými absolventy již dvě konference (listopad 1981 a listopad 1984), které měly velmi dobrou obsahovou i organizační úroveň.

Bulletin „Informace pro absolventy oboru ML sociologie “ byl založen $\mathrm{v}$ roce 1983 (první číslo vyšlo v červenci 1983, druhé v dubnu 1984 , třetí číslo je v současné době v tisku). Vydává jej katedra MĹ sociologie FF UK v Praze a Rada absolventů pro vnitřní potřebu absolventů oboru, príibližně dvakrát do roka $\mathrm{v}$ průměrném rozsahu čtyřiceti stran. Vydávání bulletinu bylo povoleno odborem kultury NVP. Obsah bulletinu schvaluje vedoucí katedry a redakční rada bulletinu. Redakční rada pracuje ve složení: ing. Věra Tauberová, CSc., předsed- kyně, doc. dr. Eduard Urbánek, CSc., dr. Květa Filipská, dr. Jana Perglerová, dr. Zdeněk Roll, dr. Jana Stankeová.

Bulletin seznamuje $s$ vývojem i aktuálními otázkami oboru ML sociologie a také s poznatky zahraniční sociologie. Publikuje zkušenosti z odborného a profesního uplatnění sociologů-absolventů katedry ML sociologie i informace o účasti našich sociologů na me zinárodních i domácích kongeresech, sympoziích, konferencích apod. Informuje rovněž o vybraných akcích Cs. sociologické společnosti, katedry a Rady absolventů, jakož i o novinkách odborné literatury, a to $\mathrm{v}$ rubrice „Publikace pro sociology".

V prvním čísle bulletinu je publikována úvodní stat' prof. dr. Karla Gally, DrSc., pod názvem „Slovo nestora československé sociologie $\mathrm{k}$ absolventům oboru ML sociologie". Je zde také interview s vedoucím katedry ML sociologie prof. dr. Antonínem Vaňkem, DrSc., o činnosti katedry a jejích aktivitách ve vztahu $\mathrm{k}$ absolventům. V rubrice „Ze sociologických pracovišt"“ jsou představena dvě pracoviště, kde působí naši absolventi. Dále následuje stat' o srovnávacím výzkumu absolventů a rubrika „Publikace pro sociology“, která prezentuje základní tituly československé i zahraniční odborné literatury. Na konci 1 . čísla je uveřejněn statut Rady absolventů a složení Rady absolventů v 1 . funkčním období.

Druhé čislo bulletinu je predevším věnováno prvnímu setkání katedry ML sociologie FF UK v Praze se svými absolventy. Je zde publikována informativní stat' o tomto setkání, dále hlavní referát vedoucího katedry a zpráva o poslání a činnosti Rady absolventů. Zajímavé jsou také publikované informace $\mathrm{z}$ vědeckého života i novinky odborné literatury. Druhé číslo bulletinu uzavírá finanční bilance hospodaření Rady absolventů a anketa $k$ problematice setkání katedry s absolventy.

Obsahové zaměření třetího čísla bulletinu je víceméně monotematické. $J$ sou $v$ něm uveřejněny informace o výuce sociologie $v$ SSSR a v NDR i bibliografie publikací pro sociology, vydaných v NDR.

$\mathrm{Z}$ uvedeného je zřejmé, že práci s absolventy 
je na katedře ML sociologie FF UK přikládán značný význam. Práce s absolventy je na katedře koncipována jako jedna $\mathrm{z}$ účinných forem spojení teorie s praxí i jako platforma konfrontace učebního programu s potřebami praxe.

Katedra ML sociologie FF UK řeší řadu závažných úkolů již tradičně se svými absolven- ty, za jejich podpory a pomoci. Tak se postupně utváří jednotná fronta učitelů a absolventů oboru ML sociologie, která zvyšuje jeho tvořivý potenciál, angažovanost, společenskou užitečnost i prestiž.

Věra Tauberová 